\title{
FABRICS REMNANTS AS A SOURCE TO CREATE SUSTAINABLE MURAL HANDICRAFTS INSPIRED BY ISLAMIC ARTS
}

\author{
Basma Mohamed Aboelyazeed Mahmoud \\ Dr., Alexandria University, faculty of specific education, Art education Department, Egypt. \\ basmaaboelyazed@yahoo.com
}

\begin{abstract}
The field of handicrafts depends on experimentation, so the researcher choose Fabrics because it is considered one of the available materials, which can be divided to natural fabrics, industrial fabrics and mixing between the two of them, it has a lot of patterns and colors, also it has porosity, suppleness and tenderness, fabrics use was limited on its original nature without any change or treatment, so the researcher tried to change this nature and turn it to become one of the sustainable materials, which can be used in handicrafts to create sustainable mural handicraft inspired by Islamic arts, The research problem is summarized in the following questions:
\end{abstract}

- Can the fabrics remnants be used as a source to create sustainable mural handicrafts?

- Can some technical treatments be applied to give the remnants of fabrics hardness and sustainability?

So the researcher assumed that:

- Some technical treatments can be applied to give the remnants of fabrics hardness and sustainability.

- The remnants of technical treated fabrics can be used to create sustainable mural handicrafts inspired by Islamic arts.

the research aim is about having benefit from the fabrics which is treated technically by the polymers, such as (polyvinyl acetate) and (transparent wood varnish), to give remnants of fabrics hardness and sustainability in the handicraft, the research Importance appears in being one of the researches that contributes to sustainable development in handicrafts field, and it includes a lot of special technical ways to use fabrics remnants, this research cares about inspiring some of geometric and floral Islamic decorative units, it is expected to have an economic payoff from this research if it has been applied in the field of small projects, this study includes six main themes:

1. defining the fabrics kinds, 2 . defining the polymers and its types which has been used in this research, 3 . The concept of sustainability, 4. the meaning of mural handicraft, 5.the Islamic decorative units types,6.the experimental application which has been applied by the students of the third year at the art education department - faculty of specific education -Alexandria university, they applied a lot of technical ways such as (rolling, quilling, crimping ) on the remnants of fabrics to implement it on the Islamic decorative units, then each one of the students made two pieces of handicrafts one of them is $40 \times 40 \mathrm{~cm}$ and the other is $20 \times 20$ 
$\mathrm{cm}$.

at the end of the experiment the researcher made a work shop to collect the students handicrafts together to form the mural handicraft, which consists of 64 handicrafts size of $40 \times 40 \mathrm{~cm}$ and 72 handicrafts size of $20 \times 20 \mathrm{~cm}$, which have been divided in two opposite walls, it was great joy for the students to see their handicrafts on the department walls one next to the other, also it was impressive mural handicraft, because it has a variety of techniques, colors, geometric and floral Islamic decorative units, and two different sizes of the handicrafts, all this give the mural handicraft variety, unity, harmony and integration, then the results and recommendations are presented followed by references.

Keywords: fabrics remnants- sustainability - mural handicrafts - the Islamic decorative units.

\section{INTRODUCTION}

Fabrics considered one of the materials that are easy to use, and characterized by being available through its kinds which can be divided to natural fiber fabrics, manmade fiber fabrics, and the mix between the two of them, also they have a lot of colors, and rich decorative units, It's hard to imagine fabrics as a mural handicrafts, where murals' materials are characterized by its sustainability "which is about taking care of avoiding depletion of natural recourses and it's connecting to sustainable development which means responding to the present needs without prejudice the ability of future generations to meet their own needs" (ezzat, 2013, p. 3), handicrafts field is depending on sustainability through using materials and recycling them to make modern, original, and nouveau handicraft, so the researcher chose the fabrics because they are available and they allow us to apply many technical ways which help to recycle it and make some technical treatments to match the nature of the material, which characterized by porosity, suppleness and tenderness, so the researcher tried to change the fabrics physical properties and give it the hardness characteristic, through using transparent polymers such as white transparent glue and varnish, to innovate mural handicraft which is characterized by hardness and sustainability, the researcher had to choose some decorative units to create the mural handicraft, so she chose Islamic art to be the source of the floral and geometric decorative units, the decorative art is known as "using shapes or images or subjects to decorate a special surface, and line is considered the main element in decoration" (Elmofty, 1997, p. 9), color groups vary in Islamic art as will, and characterized by hating emptiness, "where all dimensions of the areas are covered with floral and geometric decorative units, they are often flat, the Muslim artist didn't paint nature as it is, but he abstracted it from its contain, repetition is the most feature in Islamic art, where decorative shapes repeated on Islamic architecture, this repetition has special philosophy as if it is the praise of great god (Elmofty, 2001, p. 243), so the researcher tried to use a group of floral and geometric Islamic decorative units as a base to design the mural handicraft, and keep repetition which characterize the Islamic art, and considered investment for more than one shape to build abstract or functional formulas based on the employment of that shape or those shapes through repetitions without leaving the origin, repetition in this meaning referred to extension and continuity, which is connected with achieving movement on the surface of the two dimensional designs." (shawky, 2001, p. 225) Experimentation is the most important entrances in art to innovate handicrafts, so the researcher tried to use two types of polymers, represented in transparent polymers such as white transparent glue and varnish, to give hardness and sustainability to the used fabric remnants.

\section{RESEARCH PROBLEM}

Fabrics considered one of the available materials which has many decorative units, colors, and kinds, also it has porosity, suppleness and tenderness, fabrics use was limited on its original nature without any change or treatment, so the researcher tried to change this nature and turn it to become one of the sustainable materials, which can be used in handicrafts field to create sustainable mural handicraft inspired by Islamic arts, there was a tray to change some physical properties of fabrics through this research to use it in innovating mural handicraft, so The research problem is summarized in the following questions:

- Can the fabrics remnants be used as a source to create sustainable mural handicrafts?

- Can some technical treatments be applied to give the remnants of fabrics hardness and sustainability?

\section{RESEARCH HYPOTHESES}

The researcher assumed that: 
- Some technical treatments can be applied to give the remnants of fabrics hardness and sustainability.

- The remnants of technical treated fabrics can be used to create sustainable mural handicrafts inspired by Islamic arts.

\section{RESEARCH AIM}

It is about having benefit from the fabrics which is treated technically by the polymers, such as (polyvinyl acetate) and (transparent wood varnish), to give remnants of fabrics hardness and sustainability in the handicraft.

\section{RESEARCH IMPORTANCE}

It appears in being one of the researches that contributes to sustainable development in handicrafts field, and it includes a lot of special technical ways to use fabrics remnants, this research cares about inspiring some of geometric and floral Islamic decorative units, it is expected to have an economic payoff from this research if it has been applied in the field of small projects

\section{METHODOLOGY}

This study includes theoretical framework which deals with five main themes, and experimental framework, as the following:

Theoretical framework includes 1.defining the fabrics kinds. 2. Defining the polymers and its types which have been used in this research. 3. The concept of sustainability. 4. The meaning of mural handicraft. 5. The Islamic decorative units' types, the experimental framework was dealing with the experimental application which has been applied by the students of the third year at the art education department - faculty of specific education -Alexandria University

\section{FABRICS}

"They are made of longitudinal and cross threads which is forming the textile, these threads are called fibers, and textile is called fabrics" (Mawdoo3.com, 2017), the materials of textile are considered "the raw materials that have a hair or fibrous structure, and it has a lot of characters such as durability, elasticity, length of staple, fiber accuracy, roughness of the surface, and harvest availability for the natural fibers, beside other characters such as harmony between fibers which is forming the materials, porosity, durability, rubbery, and glossiness" ( Abdin \& Aldbbag, 2003, p. 11) the fabric type varies according to the fibers which are used in manufacturing its textile threads," textile usually is a porosity material, threads may be made of natural, or manmade fibers, or mixing between the two of them" (ar.m.Wikipedia.org., 2017), using fabrics and textile materials in handicrafts dates back to the earliest ages, forming with fabrics which is known as patchwork and other techniques which used textile fabrics in its decoration was spread, where its use spread in ancient civilization and extended through ages, till it turned to artistic production, where it was used by many artists in the east and west to produce deferent artistic works" (Slama, 2016, p. 207)

\subsection{Fabrics Fibers}

Fibers are considered one of the unique materials for these two reasons:

a. Because its shape gives it an extraordinary degree of flexibility and contributes a lot to its composition.

b. Whether fibers were natural or synthetic, their composition is often added to them better mechanical properties than if they were in a cluster shape.

"The chemical composition of each textile fiber type is determined the physical shape and properties, textile materials are usually composed of (macro molecules), small individual units are called (monomers), longchain molecules which are made of monomers are called polymers." (Omar, 2002, p. 44)

\subsection{Fabrics Types}

\subsubsection{Natural Fibers Fabrics}

"Natural fibers that exist in nature can be classified as vegetable, animal, and mineral. Vegetable fibers, found in the cell walls of plants, are cellulosic in composition. Animal fibers, produced by animals or insects, are protein in composition. The mineral fiber, asbestos, is mined from certain types of rock" (Corbman, 1983, p. 5), and It is divided to three types:

\subsubsection{Natural Cellulosic Fibers}

Those fabrics which are made from (Vegetable fibers), they are obtained from various "vegetarian sources" 
as follows:

1. Fibers of seeds hair, it is that fibers which grow on seeds covers in plants like (cotton, coconut fibers), 2.bark Fibers or fibers that descends from the stems of plants, like (flax, marijuana, jute ramie), 3.paper fibers, that exists in plants' leaves like (sisal, marijuana, pine)

\section{Another fibers from algae and roots, like (sacatan's roots fiber, Spanish algae)" (Omar, 2002, p. 71)}

\subsubsection{Animal Fibers}

"Like goat hair and wool, natural silk, all these fibers consist of protein, which is a large part of the animal body" (Sultan, 1990, p. 17)

\subsubsection{Mineral Fibers}

"These Fibers have a limited importance in the spinning and weaving industry, Asbestos Fibers which are found in the natural rocs in mines are almost the only kind of natural Mineral Fibers, crystals in these rocks have taken the form of fibers, it is found in Canada, Russia, Cyprus." (Sultan, 1990, p. 17)

\subsubsection{Physical Properties of Natural Fibers}

1. They have coherence and relatively low flexibility, and as a result they easily crimp and don't revert to their former form easily too. 2. their ability of moisture absorption are generally good, so most cellulosic fibers are slow to dry after wetting, 3. It is easy to make dyeing operations on them, 4. They are good conductor for heat and electricity, they can carry warmth away from the human body, so it is better to wear it at hot weather, and they don't make electric shocks for the one who wear clothes which are made of them. 5. Easy and fast to burn, they give yellow flame similar to what happens when paper is burned.6. Most cellulosic fibers resist and stand high and dry temperature. 7. Most insects don't attack cellulosic fibers (Omar, 2002, p. 72), So that the researcher chose natural fabrics to use it in the research experiment for all these properties".

\subsubsection{Manmade Fibers}

Manmade fibers are derived in to various sources, "they are characterized by a wide range of properties, because they are manufactured by man who controls the scientific methods in their composition, and the technological methods which are used to manufacturing them, so that they give the required properties" ( Abdin \& Aldbbag 2003 ‘p. 44). Manmade fibers are derived in to two types according to the source of the fiber constituent materials as follows:

\subsubsection{Regenerated Fibers}

The used material on it exists in nature, "such as cellulose or protein, but it has been transferred in to fibers by man, viscose, acetate are cellulosic regenerated fibers, casein and soybean are protein regenerated fibers" (Sultan, 1990, p. 17)"

\subsubsection{Synthetic Fibers}

They are the fabrics which are prepared with simple chemical compounds (Monomers), by chemical synthesis" (alnagawy, 1983, p. 79), where the raw material is made up of Petrochemicals acids, and it's formed to take the form of fibers that are similar to natural ones, (Nylon, Dacron, Orlon, Acrilan) are from their types. (Sultan, 1990, p. 18)"

\subsection{Manmade Fibers Physical Properties}

1. Thermal plasticity or heat sensitivity or the forming and manufacturing by heat, 2 . They are water dominated, so their absorption is less than the natural fabrics, and this cases difficulty in removing pigments, 3. They dry quickly when they are washed, 4. They are soft and when they turned to threads they load for exfoliation, 5. It's hard to remove oily and lipid coloring, 6. They have resistance against insects, mold fungus and bacterial growth, 7. They resist a lot of chemical materials." (Omar, 2002, p. 166)

\subsection{Mixing Natural and Manmade Fibers}

The spinning and weaving industry is currently heading towards the use of manmade fibers widely, even if they had some flaws, sometimes their qualities are less than the natural fibers but they excel in other qualities, some of the defects of manmade fibers may be overcome by mixing them with the other natural fibers, that wasn't only to reduce the cost of production but to have types of textiles their qualities are better than the qualities of textiles which are made of one type of fibers, for example nylon bears but it doesn't absorb moisture, and by mixing it with cotton we have fabric that is capable of absorbing moisture and at the same time is very durable" ( Abdin \& Aldbbag, 2003, p. 44) so it has the natural and manmade fabrics 
qualities.

Advanced fibers make fabrics more durable, while bio- materials can create elastic textures and stainresistant surfaces. Leading designers are already advocating a holistic, cradle-to cradle approach that considers the textile's entire life cycle, and minimizes its environmental impact by combining sustainability and innovation, designers are finding ways to make fashion fabrics tougher and longer lasting" (Quinn, 2013, p. 6).

\section{POLYMERS}

It's known as "a chemical compound with repeating structural units, polymers range from familiar synthetic plastics such as polystyrene to natural polymers such as DNA and proteins that are fundamental to biological structure and function. Polymers, both natural and synthetic are created via polymerization of many small molecules, known as monomers" (https://en.wikipedia.org>wiki>polymer, 2017) "Examples of synthetic polymers include nylon, polyethylene, polyester, Teflon, and epoxy. Natural polymers occur in Natural and can be extracted. They are often water - based. Examples of naturally occurring polymers are silk, wool, DNA, cellulose and proteins."(www.cmu.edu> gelfand> k12-teachers, 2017)

\subsection{White Transparent Glue (pvac):}

"Poly (vinyl acetate)(PVA, PVAc, poly (ethenyl ethanoate): commonly referred to as wood glue, white glue, carpenter's glue, school glue, Elmer's glue, or PVA glue.it is an aliphatic rubbery synthetic polymer with the formula $(\mathrm{C} 4 \mathrm{H} 6 \mathrm{O} 2) \mathrm{n}$. It belongs to the Polyvinyl esters family, with the general formula- [RCOOCHCH2]-. Its type of thermoplastic. Which is a polymer that becomes pliable or moldable above a specific temperature and solidifies up cooling."(https://en.m.wikibedia.org/wiki/polyvinyl_acetate, 2017)

\subsection{Varnish}

"A liquid that is painted on wood or paintings to protect the surface, or the hard shiny surface it produces when it is dries: polyurethane varnish provides a tough, scratch-resistant finish."(http://dictionary.cambridge.org/Dictionary/English/varnish., 2017)

"It is defined as, preparation consisting of resinous matter, as copal or lac, dissolved in an oil(oil varnish) or in alcohol(spirit varnish ) or other volatile liquid, when applied to the surface of wood, metal, ext., it dries and leaves a hard, more or less glossy, usually transparent coating" (www. Dictionary . com $>$ browse $>$ varnish., 2017) "it's used in painting iron, wood and other materials to protect it from moisture and improve its appearance" (www.marefa.org., 2017), and this was chosen by the researcher to paint the handicraft with it to make the handicraft finishing, most researches in handicraft field are directed to benefit from the remains of materials, so the researcher had benefit from the two previous polymers, to give the used fabrics hardness and isolate it from moisture, insects and various erosion factors that lead to damage fabrics, so that it become one of the sustainable materials that can be recycled and benefit from it to product mural handicrafts.

\section{SUSTAINABILITY}

"In ecology, Sustainability (from Sustain and ability) is the property of biological systems to remain diverse and productive indefinitely, so Sustainability is the endurance of systems and processes" (https://en.m.wikipedia.org>wiki>Sustainability, 2017) "It's defined in Oxford dictionary as the ability to maintain a certain percentage or level of sustainable fusion reactions, it includes Ecology which based on maintaining ecological balance and avoiding depletion of natural resources" (ezzat, 2013, p. 3)

\section{MURALS}

"The word wall with its usual image and deafness nature, free of any addition could help to improve the level of artistic and aesthetic taste, so mural means having an influential external factor to change the nature of the wall and turn it into an artistic and aesthetic value, such as mural painting or engravings."(Salem, 2016, p. 205), the handicrafts field is considered one of the fields that allows to use a lot of materials and adapt it to suit the functional purpose, so the researcher tried to implement a set of mural handicrafts inspired by Islamic arts, using the remnants of fabrics after treating them with white glue and varnish to give them hardness and Sustainability.

\section{ISLAMIC ARTS}

"Islamic Arts shows on wide land which has an artistic traditions, called Byzantine or Sassanian traditions, the establishment of Islamic philosophy, which is characterized by the monotheistic principles of Islam, it wasn't long time till the previous period has passed in which the first generation of Islamic land practiced the 
continuity of traditional art, the Islamic arts moved to second period, where these arts no longer have any connection to their traditional local sources and new features have appeared for these arts, and mad them special and unified, although there were difference between traditions in a large space of earth, which the Islam had spread in it from China to the Atlantic, then Islam reached the third period in its history, that was the period of diversity, it hasn't remain static in the face of political and social transformations which had been done under Islam shade in wide world with various policies, there was the Abbasid caliphate in Baghdad, Umayyad in Cordoba, and Fatimid in Cairo, then political units appeared with Persian or Turkish tendencies, so the specialists in these arts use the names of the political authorities which have been followed, that the history books talk about Umayyad art and the other is Abbasid, they also talk about Andalusia, Fatimid, Persians, and Ottomans, Turks arts, according to geographical division, mixed by political division" (Bahnasy, 2001, pp. 30,31), in an attempt to clarify various approaches that can never remove from its philosophical Islamic frame work, which defined its aesthetic origins that are independent of any other aesthetic origins, "decorations in Islamic art depended on line clarity and its decorative transformation and clear colors which determined with decorative lines, all the decorations were inspired by nature, transformation played a great part to show the ability to imagine and retouch" (Mrzouk, 2007, p. 93), "studying decorative subjects is very manifold as there is enormous amount of decorations, which preserves fabulous deferent styles" (Elmofty, 1997, p. 13) "Muslim artistic works with their variety were a proof of the preoccupation of the Muslim artist in producing them with all his spirit and sense, the point in the Islamic art is considered the beginning of each artistic formation, as it is in calligraphy and geometric designs"(alnagdy, 1996, p. 150)

\subsection{Geometric decorative units}

Geometric decoration division played a big role in Islamic art, squares, circles and triangles were used to create wonderful geometric forms, colors also played an important role in making the geometric relations more beautiful" (Elmofty, 1997, p. 95)

\subsection{Floral decorative units}

The Muslim artist used the leave and the stem to form decorations characterized by repetition, matching, and facing, they have a geometric hard look, the principle of abstraction and symbolism in Islamic arts, the most popular floral decorations were Arabesque" (Elmofty ‘2001 ‘p. 242), a group of geometric and floral Islamic decorative units have been chosen, to use it inside square frames "that the square characterized by balance and stability because all its sides are equal, which prove the strong balance, it consists of straight line in two directions, vertical and horizontal, and its equals in all directions so it may has a boring and monotony look, so it needs a new thinking, and using additional areas through repeating its area in vertical and horizontal contiguous directions to form a new shape, it is rectangle in its vertical or horizontal position" (zaki, 1996, p. 50), and this what the researcher tried to do when the students' handicrafts were collected together, all the following were considered:

Varying in the size, so there were two sizes for the implementing units, varying in the collected units length, which contributed to feel the movement in the final form of the mural handicraft.

\section{THE EXPERIMENTAL APPLICATION}

The students of the third year at the art education department - faculty of specific education -Alexandria University made a set of applied practices through a group of meetings, there was six meetings, each one of them was four hours, as the following:

1. applying a set of technical ways through 15 samples each one of them is $(10 \times 10) \mathrm{cm}$, that each student applies a set of technical ways such as (rolling, quilling, crimping) and uses transparent white glue to help in making the applied techniques to fabrics remnants stable, where we have hard units after glue drying, which we can collect it together according to the applied design, 2. Choosing the floral or geometric Islamic unite for each student, then employing various technical ways on fabrics remnants to have mural handicrafts inspired by Islamic arts, 3. Start the implementation of the chosen Islamic unit, and applying the technical ways on it in two areas one of them is $40 \times 40 \mathrm{~cm}$, and the other is $20 \times 20 \mathrm{~cm}$, for each student, 4 . Applying a group of technical treatments to give the handicraft hardness and sustainability, through using transparent white glue during fabrics formation, that is to close the pores, give the fabrics hardness, and keep its formation in the same shape that it had been formed in before draying, after the glue draying varnish had been used to give more hardness to the handicraft, and prevent its units from damage and insects, 5 . Finishing each handicraft which was made from fabrics remnants, to be ready for collecting the students' handicrafts and set them on the wall, 6. Establish a workshop to collect the students' handicrafts, which will form the mural handicraft, the following is a set of technical ways of the students' samples: 


\subsection{Fabrics remnants technical ways}

\subsubsection{Forming By Quilling}

It's made by cutting the fabrics for ribbons which are varying in their length and width, then rolling each one of them to form circles or shapes look like beads, fig. 1 (a,d,e,f) each one has deferent shape according to the cutting way.

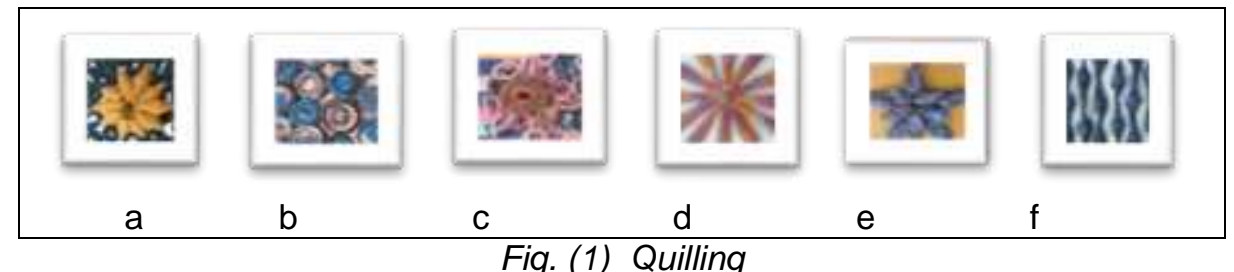

\subsubsection{Forming By Rolling}

It is varying to take different shapes such as wavy, free formation, straight or ribbed shapes, Fig.(2)

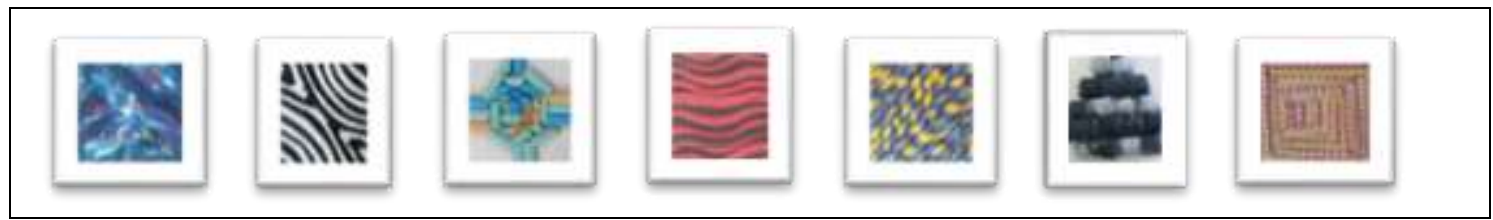

Fig. (2) Rolling

\subsubsection{Forming By Rolling With Quilling}

It is done by rolling the piece of fabric, then the formation proses is done to make a variety of circular or spiral or curved shapes ,such as (a,e,f) in Fig. (3) or use the rolling fabrics in braiding such as (b) in Fig. (2).

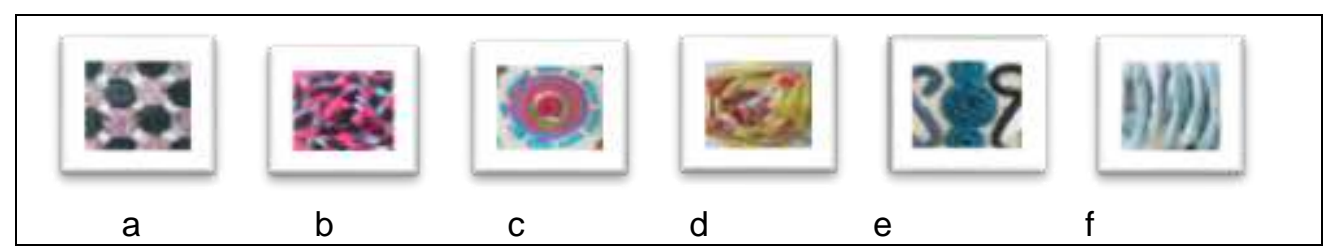

Fig. (3) Rolling With Quilling

\subsubsection{Forming By Crimping}

It is done by crimping the fabric remnants and putting the white transparent glue to keep the form of the crimped fabric, it is clear in Fig. (4) (a,b,c).

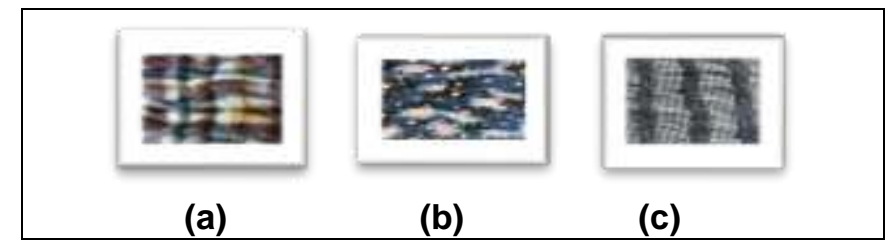

Fig. (4) Crimping

\subsubsection{Forming By Folding}

It is made by folding the fabric remnants in various shapes, such as squares, rectangles and triangles to have various units which have deferent shapes and sizes, such as Fig. (5), to use them in the handicraft after treating them with white glue.

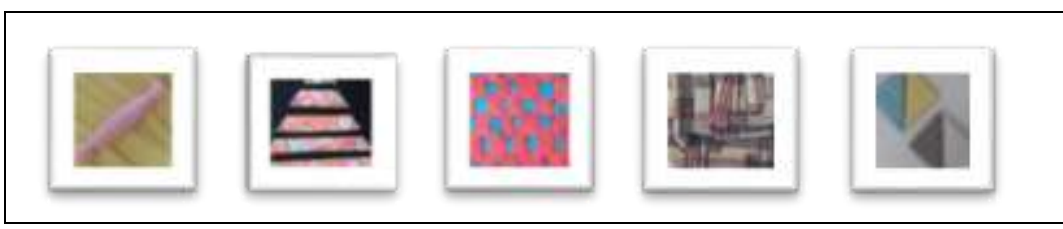


Fig. (5) Folding

\subsubsection{Forming By Braiding}

Braiding is very common to everyone, it was done in this research by using folded ribbons made of the fabrics remnants, which were treated by using white glue on it to have hardness, there are many types of Braiding the simplest one of them is the three flat braid, it's the key to more complicated flat braids. it is clear in Fig.(6).

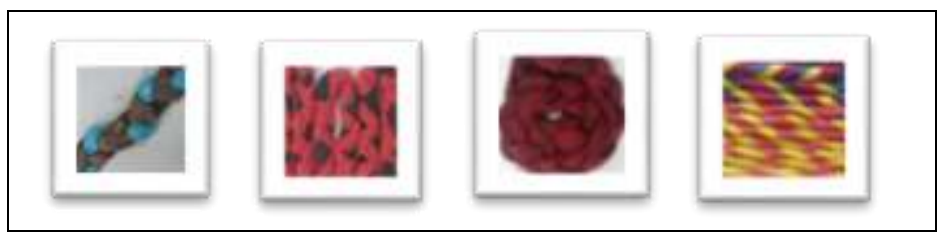

Fig.(6) Braiding

\subsubsection{Using Crochet}

It is a process of creating fabric by interlocking loops of yarn, thread, or strands of other materials using a crochet hook, The name is derived from the French term crochet, meaning 'small hook', (https://en.wikipedia.org/wiki/Crochet, 2017) it was used in this research by using ribbons made of fabrics remnants instead of threads, the white glue were used on the final piece of Crochet, to give it hardness and sustainability. Fig.(7)

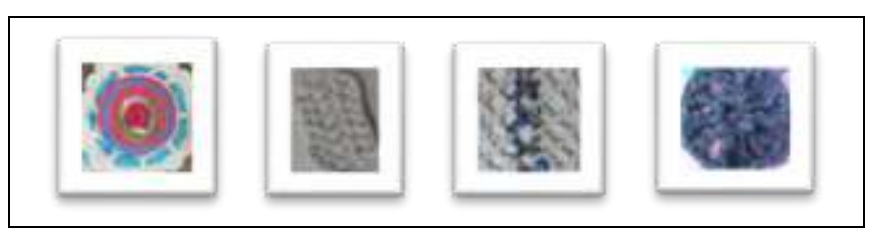

Fig.(7) Crochet

\subsubsection{Forming By Weaving}

Weaving meaning is "to form or construct something, as fabric, by interlacing threads, yarns, strips, etc." (http://www.dictionary.com/browse/weaving, 2017), in this research strips made of fabrics remnants were used in Weaving Fig.( 8), and were treated by white glue.

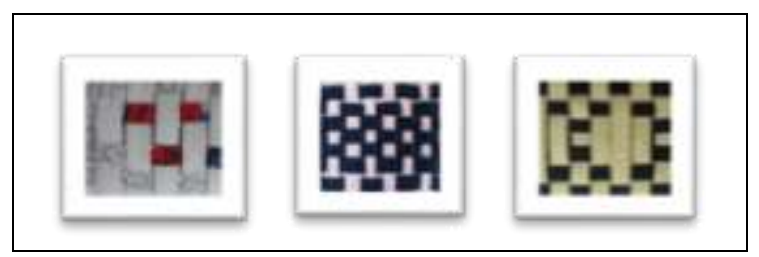

Fig.(8) Weaving

\subsection{The mural handicraft aesthetic values}

the following handicrafts are the output of the experimental application which has been applied by the students of the third year at the art education department - faculty of specific education - Alexandria university, there were two different sizes for the selected Islamic decorative unit, many aesthetic values were appeared in handicrafts which formed the mural handicraft, there were varying in colors and the used decorative Islamic units vary between geometric Fig. (9) and floral Fig. (10), the two sizes of handicrafts helped in having different lengths for the collected handicrafts to have a unique shape for the mural handicraft, there were also varying in the used technical ways in each handicraft, all this gave the mural handicraft unity and harmony which appears in using two types of decorative units and choosing colors related to the Islamic arts, the colored fabrics were beautiful because they have many colors some of them are decorated and the other are not, this gave the fabrics pieces a great verity in using it, also the technical ways in each handicraft were repeated in deferent ways according to each student's vision, the chosen material which was represented in fabrics remnants gave the mural handicraft integration by using a certain material with different technical ways, where movement appeared in the difference between the collected handicrafts lengths and sizes, there were richness in colors, technical ways, and decorative units, it was impressive mural handicraft for all who saw it.

\subsection{The mural handicraft's technical ways}


There were several technical ways which had been used in the mural handicraft such as Quilling, Rolling, Rolling With Quilling, Crimping, Folding, Braiding, Crochet, and Weaving, each student chose his own group of technical ways to use it in his handicraft according to his vision and what is suitable for the chosen Islamic decorative unit, the fabric remnants were so helpful in forming several technical ways because it is flexible material to use, also the used polymers which represented in Poly (vinyl acetate)or white glue, and varnish gave the mural handicraft hardness and protection from insects, moisture, and dust.

\subsection{The mural handicrafts' materials}

The used materials in this mural handicraft represented in two sizes of wood one of them was $20 \times 20 \mathrm{~cm}$ the other size was $40 \times 40 \mathrm{~cm}$, their thickness were $6 \mathrm{~mm}$, they had a frame with $2 \mathrm{~cm}$ width and $2 \mathrm{~cm}$ thickness, those were the base of the handicraft to stick the fabrics remnants which had been formed by many technical ways on them, fabrics remnants was the main material in this handicraft especially the ones with Natural Fibers or Mixing Natural And Manmade Fibers, because of their properties which helped a lot in the process of fabrics formation, also the two polymers which had been used on them gave the mural handicraft hardness and sustainability.

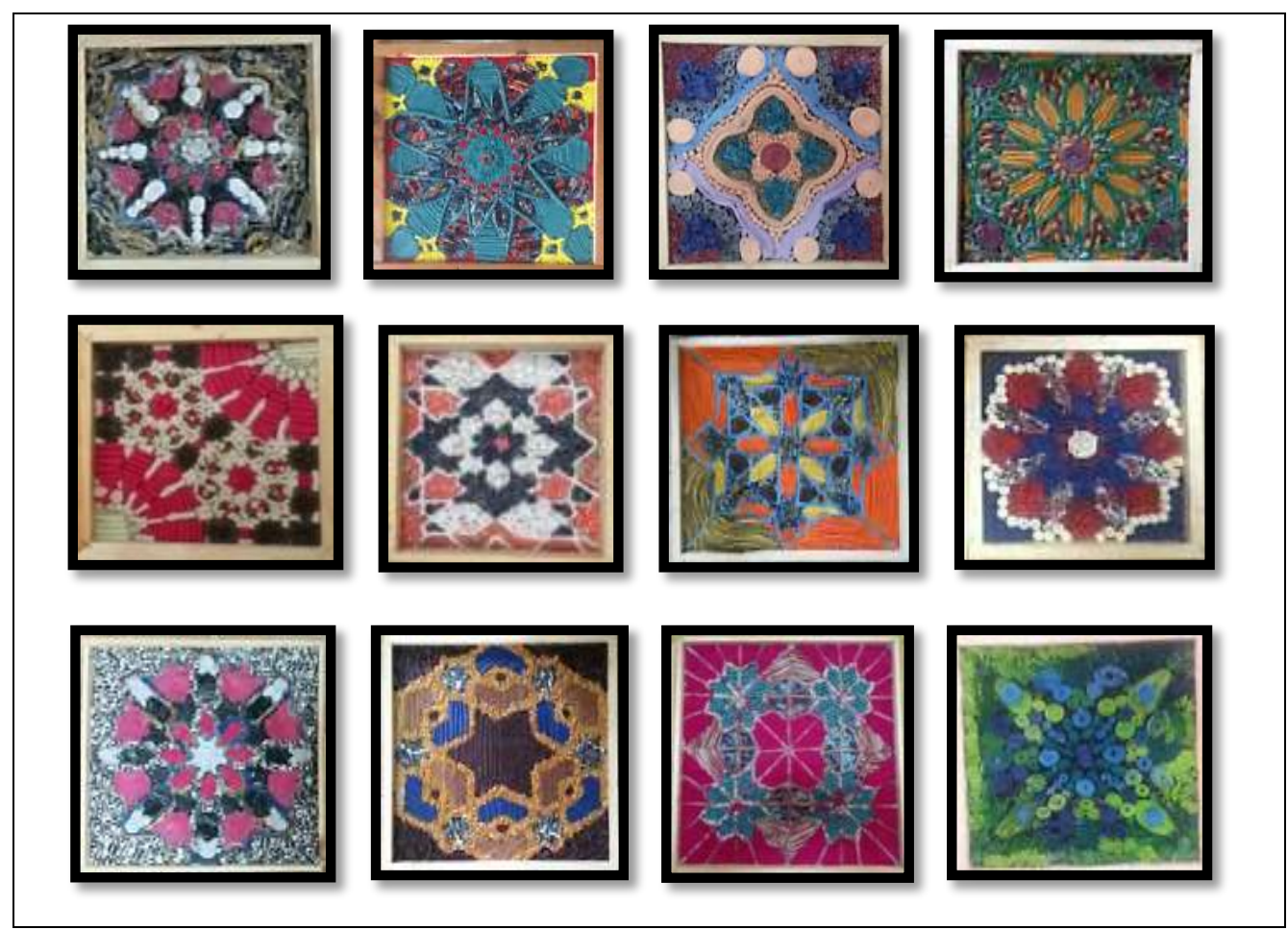

Fig.(9)

a group of handicrafts which are inspired by geometric Islamic art, and had been applied by third year students at art education department - faculty of specific education - Alexandria university 


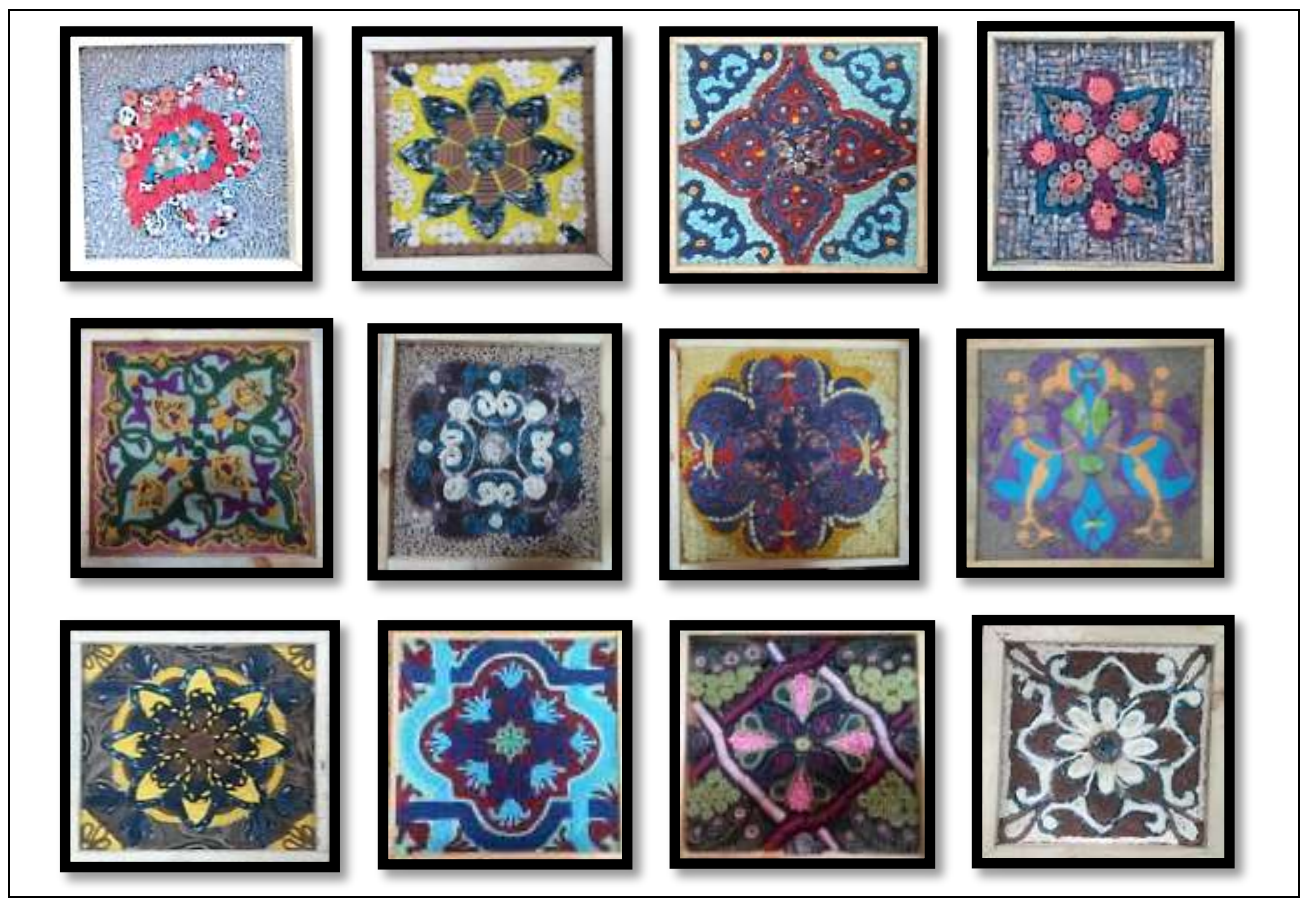

Fig. (10)

a group of handicrafts which are inspired by floral Islamic art, and had been applied by third year students at art education department - faculty of specific education - Alexandria university

\subsection{The Islamic Arts Workshop}

A two-day workshop was held to collect the mural handicraft pieces, it consists of 64 handicrafts size of $40 \times 40 \mathrm{~cm}$ and 72 handicrafts size of $20 \times 20 \mathrm{~cm}$, which have been divided in two opposite walls, the benefit of having these two sizes was considered, to have variety in the mural handicraft by having different lengths in its final shape, Fig. (2) is showing the (mural Islamic Arts handicraft Workshop), the students were so helpful and happy during this workshop, it was a great joy for the them to see their handicrafts one next to the other on the department walls, Fig. (3) shows the final mural Islamic Arts handicraft.

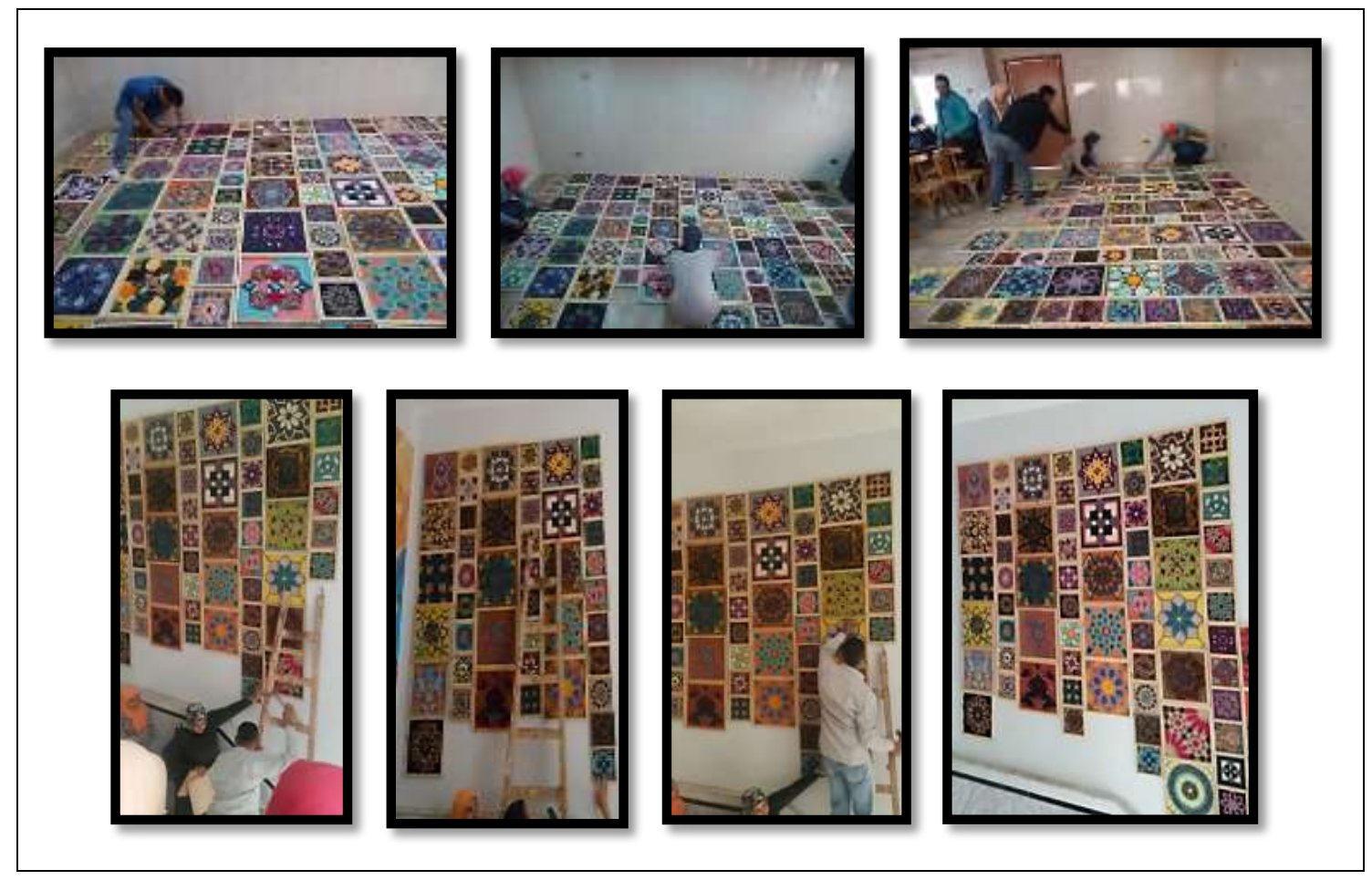

Fig. (4) the mural Islamic Arts handicraft Workshop 


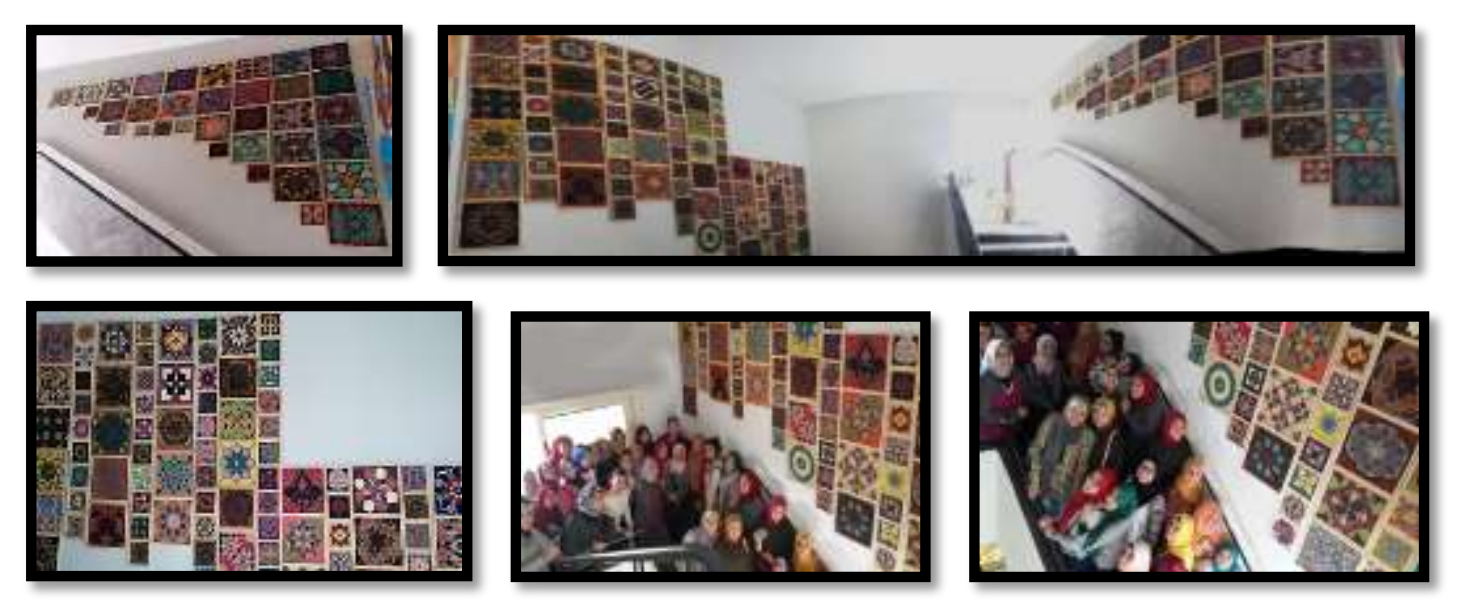

Fig. (5) the final mural Islamic Arts handicraft

\section{RESULTS}

13.1 Treated fabrics remnants can be used in innovating sustainable mural handicrafts.

13.2 The Islamic geometric and floral decorative units are an important source for innovating handicrafts.

13.3 Fabrics remnants can be useful in the field of small projects.

13.4 It was possible to benefit from the sustainability concept in handling materials with various artistic technical treatments to strengthen this concept.

13.5 It was possible to extract a group of technical ways which can be used to enrich the handicraft such as (rolling, quilling, crimping ).

13.6 the value of each handicraft appeared when they were put together the one next to the other, to have unify and spirit of collective work.

13.7 Varity and uniqueness had appeared in handicrafts through emphasizing on individual differences, where every student was free to choose his own decorative Islamic unit, his suitable group of colors, and the technical ways which are used in the handicraft.

\section{RECOMMENDATIONS}

the researcher recommends the following :

14.1 researching in the possibility of material recycling, with suitable treatments for each material.

14.2 Innovating new technical treatments which are suitable to the material nature, to achieve sustainability in the handicraft.

14.3 thinking out of the box in the handicrafts field through innovating new technical treatments to each used material in this field.

14.4 Expanding the handicraft area, where it is not limited to be only in small sizes.

14.5 Encouraging the students to work collectively, and appreciating the other, where the handicraft value appears through the student effort.

14.6 Emphasizing on principle of individual differences.

14.7 Emphasizing on the importance of cooperative work, and the importance of the other through making the students free to choose their own decorative units and innovate their own technical ways in using materials. 


\section{REFERENCE LIST}

Abdin .A .Aldbbag (2003): Studies in Textile and foundations of implementation of clothing .Cairo, dar alfekr alaraby.

Alnagawy. A .F.(1983): manmade fibers technology and its mixtures, Alexandria, monshaat almaaref

Alnagdy ،O،.(1996):design alphabetical,Egyptian book Association.

Bahnasy ‘A‘.(2002) .north, south- dialogue in Islamic art critical comparative study .sharjah: daerat alealam walthqafa

Corbman, B. P., 1983. Textiles Fibers To Fabrics. United States, McGraw-Hill, Inc.

Elmofty ‘A،.(1997) .art of decoration and securitization .Damascus, dar Damascus.

Elmofty ‘A‘.(2001) .Encyclopedia of historical decoration .Damascus, dar Damascus.

Ezzat, N. E. G. E. M., 2013. the role of external advertising in achieving sustainable development. faculty of art education forth international conference, art and sustainable development,cairo.

Mrzouk ، ‘.(2007) .decoration encyclopedia. ibn sina library.

Omar, M. I., (2002). Technology Of Manufactured Fibers. damascus, cairo, Dar alons, dar alkotob alelmia.

Quinn ‘B،.(2013): textile visionaries innovation and sustainability in textile design .London, Laurence king publishing Ltd.

Salem, G. S. G., (2016), The Aesthetic Styles In Ceramic Murals In Architecture And Contemporary Interior Architecture. Amesea, vol. 5,6.

Shawky ، ‘.(2001), Art and design .cairo, zhraa asharqe.

Slama ‘R .H،.(2016): Creativety as an approach for vivification of heritage crafts towards world promotion. Amesea.vol.5,6.

Sultan ‘M .A،.(1990), manmade fibers .alexandria: monshat almaaref.

Zaki ،M .a .a. (1996), Art And Design, Almousky press.

Mawdoo3.com(2017).

http://dictionary.cambridge.org/Dictionary/English/varnish. (2017).

https://en.m.wikibedia.org/wiki/polyvinyl_acetate. (2017).

https://en.m.wikipedia.org<wiki<Sustainability. (2017).

https://en.wikipedia.org<wiki<polymer(2017).

www. Dictionary. com > browse >varnish., (2017)..

www.cmu.edu < . .gelfand <k12-teachers,(2017).

www.marefa.org., 2017. www.marefa.org. (2017). 